\title{
Pengaruh Pemangkasan Pucuk dan Jarak Tanam terhadap Pertumbuhan dan Produksi Bibit Ubi Jalar (Ipomoea batatas L.)
}

\author{
Effect of Tip Pruning and Planting Distance to the Growth and Cutting Production of Sweet Potato \\ (Ipomoea batatas L.)
}

\section{Devi Novianti dan Asep Setiawan*}

Departemen Agronomi dan Hortikultura, Fakultas Pertanian, Institut Pertanian Bogor (Bogor Agricultural University), Jl. Meranti, Kampus IPB Darmaga, Bogor 16680, Indonesia Telp. \& Faks. 0251-8629353 e-mail: agronipb@indo.net.id

*Penulis untuk korespondensi : asetiawan_agh@yahoo.com

Disetujui : 15 Januari 2018 / Published Online 23 Januari 2018

\begin{abstract}
This study was conducted to determine effect of tip pruning and planting distance to the growth and cutting production of sweet potato (Ipomoea batatas L.). The research design was randomized complete block design (RCBD) with two factors and three replications. The first factor is tip pruning: Pruned and unpruned. The second is planting distance: $100 \mathrm{~cm} \times 30 \mathrm{~cm}, 100 \mathrm{~cm} \times 25 \mathrm{~cm}$ and $100 \mathrm{~cm} \times 15 \mathrm{~cm}$. Research shows that the treatment of tip pruning influence to increasing long of the trunks, the number and length of the primary branches, the number and length of the secondary branches, as well as the number of $25 \mathrm{~cm}$ length stem and tip cutting. Planting distance treatment increase the number and length of the primary branches, as well as the number of $25 \mathrm{~cm}$ length tip cutting. Production of sweet potato cutting is highest at combination treatment of tip cutting and planting distance of $100 \mathrm{~cm} \times 30 \mathrm{~cm}$ produce higher number of cutting.
\end{abstract}

Keywords: stem cutting, tip cutting

\begin{abstract}
ABSTRAK
Penelitian ini dilakukan untuk mengetahui pengaruh pemangkasan pucuk dan jarak tanam terhadap pertumbuhan dan produksi bibit ubi jalar (Ipomoea batatas L.). Penelitian ini menggunakan rancangan faktorial RKLT dengan dua faktor dan tiga ulangan. Faktor pertama adalah pemangkasan, terdiri atas pemangkasan dan tanpa pemangkasan. Faktor kedua adalah jarak tanam, terdiri atas jarak tanam $100 \mathrm{~cm} \times 30$ $\mathrm{cm}, 100 \mathrm{~cm} \times 25 \mathrm{~cm}$ dan $100 \mathrm{~cm} \times 15 \mathrm{~cm}$. Hasil penelitian menunjukkan bahwa perlakuan pemangkasan berpengaruh terhadap peningkatan panjang batang, jumlah dan panjang cabang primer, jumlah dan panjang cabang sekunder, serta jumlah stek pucuk ukuran $25 \mathrm{~cm}$. Perlakuan jarak tanam berpengaruh terhadap peningkatan jumlah dan panjang cabang primer serta jumlah stek pucuk ukuran $25 \mathrm{~cm}$. Produksi bibit ubi jalar lebih banyak dihasilkan pada perlakuan pemangkasan dan jarak tanam $100 \mathrm{~cm}$ x $30 \mathrm{~cm}$.
\end{abstract}

Kata kunci : stek batang, stek pucuk 


\section{PENDAHULUAN}

Ubi jalar (Ipomoea batatas L.) atau ketela rambat merupakan tanaman pangan yang banyak mengandung karbohidrat. Kandungan karbohidrat tinggi menjadi potensi besar sebagai bahan pangan pengganti beras. Substitusi ubi jalar untuk beras dapat mendukung tercapainya program diversifikasi pangan. Menurut Hasyim dan Yusuf (2008), produktivitas ubi jalar cukup tinggi jika dibandingkan dengan padi. Produktivitas ubi jalar lebih dari 30 ton/ha dengan masa panen sekitar 4 bulan, sedangkan produktivitas padi 5 ton/ha dengan masa panen 3 bulan. Menurut Balitbangtan (2008), produktivitas ubi jalar cukup tinggi dibandingkan dengan beras dan ubi kayu. Produktivitas dipengaruhi oleh mutu bibit, sifat tanah, dan pemeliharaannya. Rata-rata produktivitas nasional ubi jalar mencapai 12 ton/ha, masih lebih tinggi jika dibandingkan dengan rata-rata produktivitas nasional padi sebesar 5 ton/ha. Menurut BPS (2015), tahun 2011 sampai 2015 produktivitas nasional ubi jalar cenderung stagnan dan luas area panen mengalami penurunan.

Teknik perbanyakan tanaman ubi jalar yang sering dilakukan adalah dengan stek batang atau stek pucuk. Bibit berupa stek batang maupun stek pucuk harus memenuhi syarat diantaranya, bibit berasal dari varietas unggul, bibit minimal berumur 2 bulan, pertumbuhan bibit dalam keadaan sehat dan normal (Kemenristek, 2000). Penggunaan varietas unggul akan berdampak pada kesejahteraan petani dan konsumen apabila bibit yang digunakan merupakan bibit berkualitas (Djufry, 2011). Bibit yang dibutuhkan untuk setiap satu hektar lahan budidaya cukup tinggi sekitar 40.000 bibit dengan jarak tanam $100 \mathrm{~cm}$ x $25 \mathrm{~cm}$ (Widowati, 2000). Menurut Santoso et al. (2008), teknik perbanyakan vegetatif melalui stek yang efisien dan efektif merupakan hal penting bagi pertanaman untuk menghasilkan bibit yang baik.

Kegiatan produksi bibit sangat dibutuhkan karena bibit merupakan sarana produksi utama penghasil ubi jalar. Kegiatan produksi bibit dilakukan untuk memenuhi kebutuhan terhadap bibit dan menghasilkan bibit yang berkualitas tinggi dalam jumlah yang cukup (Djufry et al., 2011). Kualitas bibit akan menentukan tinggi rendahnya hasil produksi ubi jalar. Penanaman dan pemeliharaan yang baik akan mendukung pertumbuhan dan perkembangan bibit. Bibit yang akan dijadikan bahan tanam harus diperhatikan sejak awal penanaman sampai siap dijadikan bahan perbanyakan. Menurut Sasongko (2009), salah satu upaya yang dapat dilakukan untuk memenuhi kebutuhan terhadap bibit adalah melalui perbaikan cara budidaya.

Perbaikan cara budidaya merupakan upaya yang dilakukan untuk meningkatkan produksi bibit ubi jalar. Perbaikan cara budidaya yang dapat dilakukan adalah pemangkasan pucuk dan pengaturan jarak tanam. Menurut Purnama et al. (2013), pengaturan jarak tanam merupakan salah satu teknik budidaya yang dapat dilakukan untuk meningkatkan produksi. Menurut Panggabean (2014), pemangkasan merupakan upaya mengurangi bagian tanaman yang tidak penting dengan tujuan mengoptimalkan bagian tanaman yang penting untuk pertumbuhan dan produksi. Menurut Srirejeki et al. (2015), pemangkasan pucuk menyebabkan dominansi apikal terhenti sehingga pertumbuhan tunas dan cabang makin banyak karena akumulasi auksin pada daerah pucuk dialirkan ke tunas-tunas lateral. Menurut sutapradja (2008), pada dasarnya pengaturan jarak tanam digunakan agar tanaman tidak mengalami persaingan sehingga dapat tumbuh dengan baik. Menurut Abadi et al. (2013), jarak tanam yang lebih luas akan menghasilkan pertumbuhan tanaman yang lebih baik karena kompetisi antar tanaman lebih sedikit sehingga setiap tanaman dapat memaksimalkan penggunaan air, hara, cahaya, dan ruang tumbuh. Menurut Suharsi et al. (2013), pemangkasan dan jarak tanam merupakan faktor-faktor yang perlu diteliti untuk mendapatkan teknologi produksi benih bermutu.

\section{BAHAN DAN METODE}

Penelitian ini dilaksanakan di Kebun Percobaan IPB yang berlokasi di Desa Cikarawang, Kabupaten Bogor, Jawa Barat. Penelitian ini dilaksanakan pada bulan Desember 2015 sampai bulan Mei 2016. Bahan yang digunakan dalam penelitian ini adalah stek pucuk ubi jalar varietas cilembu, pupuk urea, SP-36, $\mathrm{KCl}$, pupuk kandang, insektisida, fungisida, dan kapur pertanian. Alat yang digunakan adalah alat tulis, kamera, penggaris, timbangan, dan alat-alat pertanian. Uji Duncon Multiple Range Test (DMRT) dilakukan apabila terdapat pengaruh nyata ( $\mathrm{F}$ hitung $>\mathrm{F}$ tabel) terhadap parameter yang diamati menggunakan software SAS versi 9.1

Penelitian ini menggunakan rancangan faktorial RKLT (rancangan kelompok lengkap teracak) dengan dua faktor dan tiga ulangan. Faktor pertama adalah pemangkasan pucuk yang terdiri atas dua taraf perlakuan yaitu tanpa pemangkasan dan pemangkasan. Faktor kedua adalah jarak tanam yang terdiri atas tiga taraf 
perlakuan yaitu $100 \mathrm{~cm}$ x $30 \mathrm{~cm}, 100 \mathrm{~cm} \mathrm{x} 25 \mathrm{~cm}$, dan $100 \mathrm{~cm}$ x $15 \mathrm{~cm}$. Setiap kombinasi perlakuan diulang tiga kali sehingga diperlukan 3 × 2 × $3=$ 18 petak satuan percobaan. Luas tiap petak pecobaan $5 \mathrm{~m}$ x $2 \mathrm{~m}=10 \mathrm{~m}^{2}$. Total lahan yang diperlukan $18 \times 10 \mathrm{~m}^{2}=180 \mathrm{~m}^{2}$. Petak percobaan dibuat guludan dengan ukuran masing-masing 5 $\mathrm{m} \times 0,5 \mathrm{~m}$.

Bibit yang akan digunakan merupakan bibit varietas cilembu yang diambil dari bagian pucuk. Stek pucuk yang digunakan memiliki lima buku. Tiga buku bagian terbawah ditanam dan disisakan dua buku bagian teratas. Bibit ubi jalar ditanam pada tengah guludan dengan jarak antar tanaman disesuaikan dengan perlakuan. Stek yang digunakan adalah stek pucuk yang diambil dari lahan pembibitan yang telah dipersiapkan sebelumnya. Aplikasi pupuk dilakukan dua kali dengan menggunakan pupuk tunggal. Pemupukan dilakukan dengan sistem larikan (alur). Pemupukan dengan sistem larikan mula-mula dibuat larikan kecil di sepanjang guludan sejauh 7-10 cm dari batang tanaman sedalam $5-7 \mathrm{~cm}$, kemudian sebarkan pupuk secara merata ke dalam larikan sambil ditimbun dengan tanah. Menurut Kemenristek (2000), Dosis pupuk yang digunakan adalah $100 \mathrm{~kg}$ urea ha ${ }^{-1}, 50 \mathrm{~kg} \mathrm{SP}-36 \mathrm{ha}^{-1}$, dan 100 $\mathrm{KCl} \mathrm{ha}{ }^{-1}$. Pemupukan pertama dilakukan saat umur 3 MST sebanyak 2/3 dosis urea ditambah 1/3 SP-36 dan KCl. Pemupukan kedua saat umur 6 MST sebanyak 1/3 dosis urea ditambah 2/3 SP36 dan $\mathrm{KCl}$.

Pengamatan dilakukan terhadap tanaman contoh dari tiap petak percobaan yang meliputi : A. Pengamatan pertumbuhan vegetatif, dilakukan saat tanaman berumur 2 MST sampai 8 MST

1. Panjang batang, yaitu panjang batang diukur dari pangkal batang sampai ujung batang atau titik tumbuh

2. Jumlah cabang primer, yaitu jumlah cabang yang tumbuh di setiap ketiak daun batang utama

3. Jumlah cabang sekunder, yaitu jumlah cabang yang tumbuh di setiap ketiak daun cabang primer

4. Panjang cabang primer, yaitu panjang cabang > $1 \mathrm{~cm}$ yang diukur dari tempat tumbuh di batang utama sampai titik tumbuh cabang primer

5. Panjang cabang sekunder, yaitu panjang cabang $>1 \mathrm{~cm}$ yang diukur dari tempat tumbuh di cabang primer sampai titik tumbuh cabang sekunder

B. Panen hasil bibit, dilakukan saat tanaman berumur 9 MST

1. Jumlah stek batang berukuran $25 \mathrm{~cm}, 20 \mathrm{~cm}$, dan $15 \mathrm{~cm}$
2. Jumlah stek pucuk berukuran $25 \mathrm{~cm}, 20$, dan $15 \mathrm{~cm}$

C. Panen hasil umbi, dilakukan saat tanaman berumur 18 MST

4. Jumlah umbi berukuran kecil (<150gram), sedang (150-200 gram), dan besar (200-300 gram)

\section{HASIL DAN PEMBAHASAN}

\section{Kondisi Umum}

Penelitian ini dilaksanakan di lokasi dengan ketinggian tempat $230 \mathrm{~m}$ di atas permukaan laut. Tekstur dan Struktur tanah di lahan percobaan adalah liat dan gembur. Tanah sangat lengket dan licin pada kondisi basah dan guludan mengalami keretakan saat kondisi kering. Tanaman ubi jalar cocok ditanam pada tanah lempung berpasir untuk mendukung perkembangan umbi. Kondisi tanah seperti ini akan menghambat perkembangan umbi. Suhu rata-rata di tempat penelitian sekitar 26,47 ${ }^{\circ} \mathrm{C}$ dengan kelembapan udara rata-rata 86,27\% (Tabel Lampiran 3). Kondisi iklim seperti ini sesuai dengan syarat tumbuh tanaman ubi jalar, dimana ubi jalar dapat tumbuh pada suhu sekitar $20{ }^{\circ} \mathrm{C}$ sampai $26{ }^{\circ} \mathrm{C}$ dengan kelembapan udara rata-rata $88 \%$.

Pertumbuhan tanaman pada kondisi awal cukup baik (Gambar Lampiran 1) dengan rata-rata daya tumbuh sekitar 79,33\% (Tabel Lampiran 2). Pengamatan daya tumbuh dilakukan pada umur 1 MST. Petak percobaan pada perlakuan tanpa pemangkasan dengan jarak tanam $100 \mathrm{~cm}$ x $15 \mathrm{~cm}$ pada guludan kedua, seluruh bibit mengalami kematian disebabkan karena gagalnya bibit dalam inisiasi perakaran. Bibit mati dengan kondisi bagian pucuk patah dan berwarna coklat kehitaman dan terus menjalar keseluruh bagian bibit. Penentuan tanaman contoh dilakukan secara acak pada umur 2 MST. Setiap petak memiliki 6 tanaman contoh. Penentuan tanaman contoh dilakukan setelah pertumbuhan tanaman serempak dan kondisi stabil sehingga pengamatan cabang primer dan sekunder dimulai pada umur $3 \mathrm{MST}$, sedangkan pengamatan panjang batang sudah mulai dilakukan saat umur 2 MST untuk mengetahui panjang awal batang sebelum dilakukan pemangkasan.

Tanaman mulai terserang hama pada umur 2 MST. Hama yang menyerang antara lain ulat, belalang, kepik, serta penggerek batang dan umbi. Hama ulat, belalang, dan kepik menyerang bagian daun yang menyebabkan daun berlubang dan bergerigi pada bagian pinggir (Gambar Lampiran 4), sedangkan penggerek batang dan umbi menyerang bagian batang dan umbi yang menyebabkan batang patah, umbi berlubang, dan 
dibekas gerekan ada kotoran hama berwarna hitam, selain itu serangan hama ini juga menyebabkan daun layu dan akhirnya cabang mati. Tanaman juga mulai terserang penyakit kudis pada umur 3 MST yang disebabkan oleh Elsionoe batatas dengan gejala daun dan batang berbintik warna kuning kecoklatan serta bentuk daun keriting (Gambar Lampiran 4). Pengendalian hama dan penyakit tidak mendominasi pada minggu-minggu awal pertanaman, sehingga pengendalian dilakukan pada umur 5 MST dengan deltamethrin 2,5\% untuk hama dan mankozeb $80 \%$ untuk penyakit.

Gangguan gulma pada petak percobaan dimulai sejak pertanaman berumur 2 MST. Pengendalian gulma dilakukan secara manual dengan cangkul dan kored. Pengendalian gulma dilakukan bersamaan dengan pembumbunan dan pembalikan batang agar lebih efisien tenaga dan waktu. Menurut Abadi et al., (2013), gulma mempunyai kebutuhan dasar yang sama untuk pertumbuhan dan perkembangan seperti air, hara, cahaya, $\mathrm{CO} 2$, dan ruang tumbuh. Kondisi ini dapat menyebabkan persaingan antara gulma dan tanaman sehingga pertumbuhan dan perkembangan tanaman terhambat.

Pembalikan batang dan pembumbunan dilakukan pada umur 3 MST dan 6 MST. Menurut Rahmiana et al. (2015), pembalikan batang dilakukan untuk tujuan sanitasi kebun, mencegah terbentuknya akar adventif, dan memperlancar proses fotosintesis. Menurut Yudianto et al. (2015), pembumbunan harus dilakukan pada tanaman umbi-umbian. Pembumbunan dilakukan untuk membuat tanah menjadi lebih gembur sehingga perkembangan umbi dalam tanah dapat maksimal. Pembumbunan juga akan memberikan perlindungan pada umbi dari serangan hama.

Hasil penelitian menunjukkan bahwa perlakuan pemangkasan menghasilkan pertumbuhan rata-rata panjang batang lebih pendek dari perlakuan tanpa pemangkasan, sebaliknya perlakuan pemangkasan menghasilkan pertumbuhan rata-rata panjang cabang primer yang lebih tinggi dari perlakuan tanpa pemangkasan selama waktu pengamatan dari umur 2 MST sampai 8 MST. Pemangkasan tidak berpengaruh nyata terhadap jumlah cabang primer kecuali pada umur 4 MST, dimana perlakuan pemangkasan menghasilkan rata-rata jumlah cabang primer lebih banyak dari perlakuan tanpa pemangkasan. Pemangkasan juga berpengaruh nyata terhadap jumlah dan panjang cabang sekunder pada umur 6 MST sampai 8 MST, dimana perlakuan pemangkasan menghasilkan rata-rata jumlah dan panjang cabang sekunder lebih tinggi dari perlakuan tanpa pemangkasan. Pemangkasan berpengaruh nyata terhadap jumlah stek batang dan stek pucuk, dimana perlakuan pemangkasan menghasilkan stek batang dan stek pucuk yang lebih banyak dari perlakuan tanpa pemangkasan. Jarak tanam berpengaruh nyata terhadap jumlah dan panjang cabang primer dimana jarak tanam $100 \mathrm{~cm} \quad \mathrm{x} \quad 30 \mathrm{~cm}$ menghasilkan pertumbuhan paling tinggi dari jarak tanam lainnya. Jarak tanam $100 \mathrm{~cm}$ x $30 \mathrm{~cm}$ menghasilkan rata-rata jumlah stek pucuk lebih banyak dari jarak tanam lainnya. Rekapitulasi sidik ragam pengaruh pemangkasan pucuk, jarak tanam, dan interaksi antara keduanya terhadap pertumbuhan vegetatif, hasil panen bibit, dan hasil panen umbi dapat dilihat pada Tabel 1.

\section{Pertumbuhan Vegetatif}

Panjang Batang. Perlakuan pemangkasan berpengaruh nyata terhadap panjang batang selama pengamatan umur 2 MST sampai 8 MST (Tabel 1). Pengaruh pemangkasan terhadap panjang batang (Tabel 2) menunjukkan bahwa perlakuan tanpa pemangkasan berbeda nyata dengan perlakuan pemangkasan. Perlakuan tanpa pemangkasan memiliki panjang batang lebih tinggi dari perlakuan pemangkasan. Menurut Srirejeki et al. (2015), pemangkasan pucuk pada tanaman buncis menghentikan dominansi apikal sehingga pertumbuhan panjang batang lebih lambat. Penelitian yang dilakukan oleh Munawaroh dan Aziz (2014) menjelaskan bahwa perlakuan pemangkasan pada tanaman torbangun dapat menghambat pertambahan tinggi tanaman.

Panjang batang rata-rata pada perlakuan tanpa pemangkasan mencapai 101,2 cm, sedangkan pada perlakuan pemangkasan panjang batang rata-rata hanya $12,1 \mathrm{~cm}$. Menurut Balitbangtan (2001), panjang batang ubi cilembu berkisar antara $80 \mathrm{~cm}$ sampai $130 \mathrm{~cm}$. 
Bul. Agrohorti 6 (1): 140-150 (2018)

Tabel 1. Rekapitulasi hasil analisis ragam pengaruh pemangkasan pucuk (PP), jarak tanam (JT), dan interaksinya $(\mathrm{PP} * \mathrm{JT})$ terhadap pertumbuhan vegetatif, hasil panen bibit dan hasil panen umbi

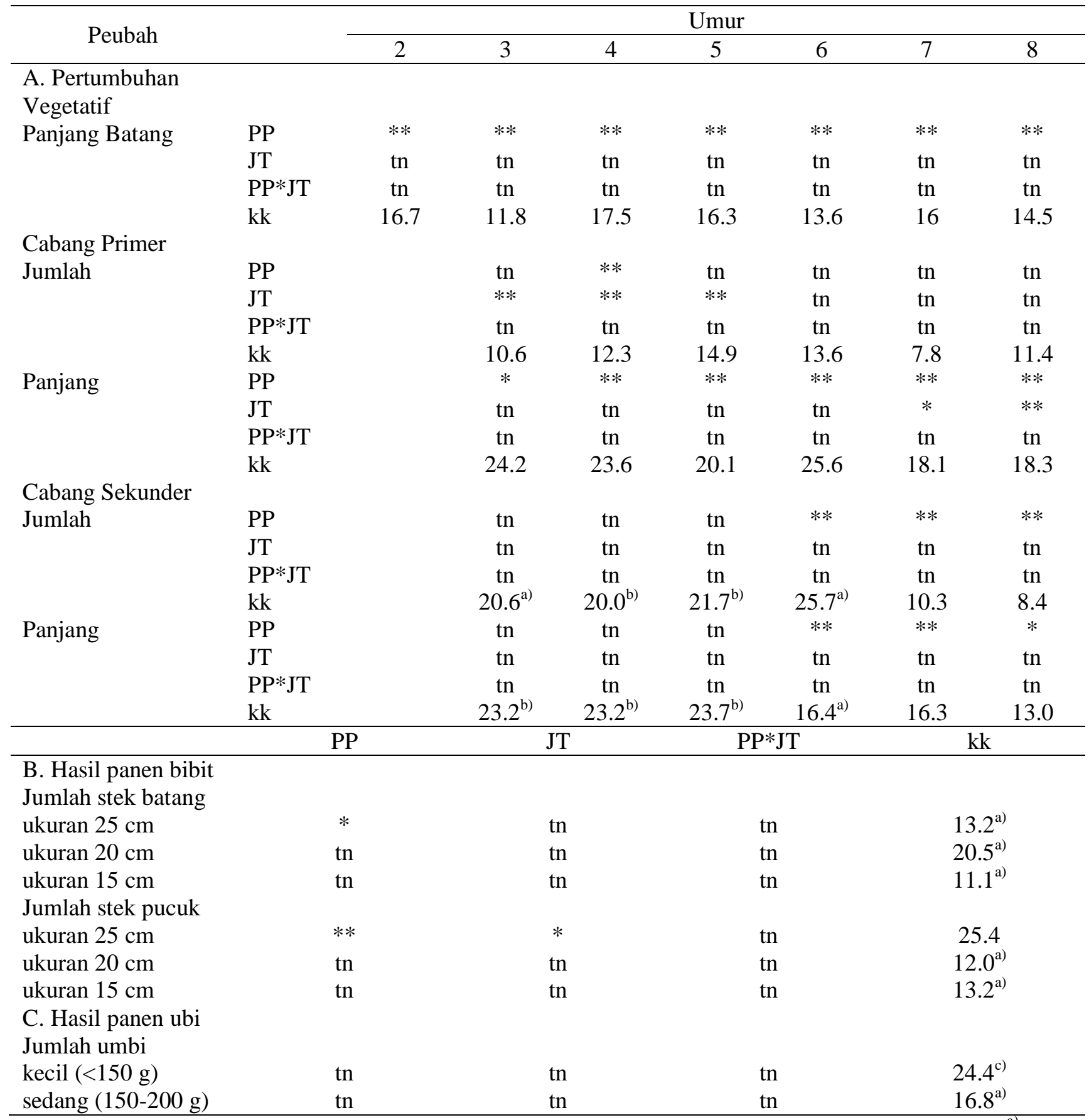

Keterangan : *: nyata pada uji F 5\%; **: nyata pada uji $\mathrm{F} 1 \%$; tn: tidak nyata; kk : koefisien keragaman (\%); ${ }^{\text {a) }}$ hasil transformasi $\sqrt{\mathrm{x}}+0.5{ }^{\text {b) }}$ : hasil transformasi $\sqrt{\mathrm{x}}+1{ }^{\mathrm{c}}{ }^{\mathrm{c}}$ : hasil transformasi $\sqrt{\mathrm{x}}+2$.

Batang utama mengandung cadangan makanan sehingga tanaman yang memiliki batang utama lebih tinggi akan memiliki cadangan makanan yang lebih banyak. Cadangan makanan ini sebagai sumber energi, sehingga tanaman dengan cadangan makanan lebih banyak akan memiliki pertumbuhan tanaman yang lebih baik (Irawati dan Setiari, 2006). Menurut Arifin (2015), stek buah naga dengan cadangan makanan yang lebih banyak akan memiliki pertumbuhan tanaman lebih cepat. 
Tabel 2. Pengaruh pemangkasan pucuk terhadap panjang batang

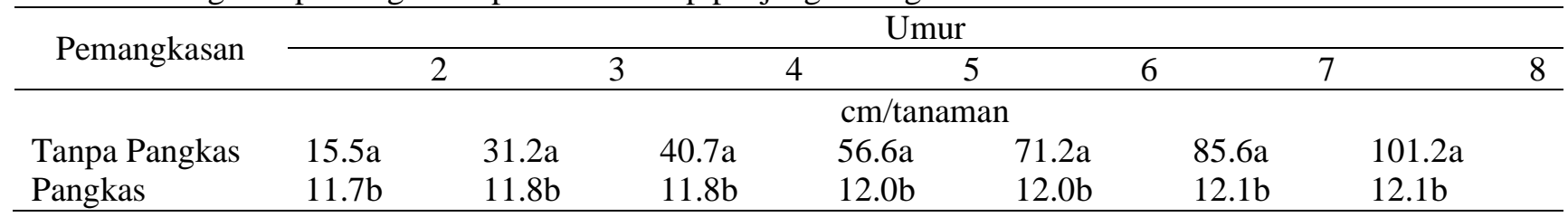

Keterangan: angka yang diikuti oleh huruf yang sama pada kolom yang sama tidak berbeda nyata pada uji lanjut DMRT pada taraf $\alpha=5 \%$

Jumlah dan Panjang Cabang Primer. Cabang primer merupakan cabang yang tumbuh pada ketiak daun di batang utama. Awal penanaman biasanya ubi jalar belum memiliki cabang primer. Cabang primer mulai tumbuh pada umur 1 MST ditandai dengan pertumbuhan tunas kemudian tumbuh cabang primer pada minggu-minggu berikutnya.

Perlakuan pemangkasan berpengaruh nyata terhadap jumlah cabang primer pada umur 4 MST (Tabel 1). Jumlah cabang primer pada perlakuan pemangkasan lebih tinggi dari perlakuan tanpa pemangkasan. Perlakuan pemangkasan memiliki jumlah rata-rata 5 cabang primer, sedangkan pada perlakuan tanpa pemangkasan memiliki jumlah rata-rata 4 cabang primer. Jumlah cabang primer mulai dihitung pada tunas-tunas lateral yang memiliki panjang lebih dari $1 \mathrm{~cm}$. Penelitian yang dilakukan oleh Panggabean (2014) menjelaskan bahwa perlakuan pemangkasan pada bengkuang berpengaruh nyata terhadap jumlah cabang pada umur 7 MST.

Perlakuan jarak tanam berpengaruh nyata terhadap jumlah cabang primer pada umur 3 MST sampai 5 MST (Tabel 1). Pengaruh jarak tanam terhadap jumlah cabang primer (Tabel 3) menunjukkan bahwa perlakuan jarak tanam 100 $\mathrm{cm} \times 30 \mathrm{~cm}$ berbeda nyata dengan jarak tanam $100 \mathrm{~cm} \mathrm{x} 25 \mathrm{~cm}$ dan $100 \mathrm{~cm} \times 15 \mathrm{~cm}$. Pengamatan pada umur 5 MST menunjukkan bahwa jarak tanam $100 \mathrm{~cm}$ x $30 \mathrm{~cm}$ menghasilkan jumlah cabang primer tertinggi dengan rata-rata 7 cabang, sedangkan jumlah cabang primer terendah pada jarak tanam $100 \mathrm{~cm} \times 15 \mathrm{~cm}$ dengan rata-rata 5 cabang.

Tabel 3. Pengaruh jarak tanam terhadap jumlah cabang primer

\begin{tabular}{rccc}
\hline \multirow{2}{*}{ Jarak Tanam } & \multicolumn{3}{c}{ Umur } \\
\cline { 2 - 4 } & 3 MST & 4 MST & 5 MST \\
\hline & & $\sum$ cabang/tanaman & $7.0 \mathrm{a}$ \\
$100 \mathrm{~cm} \times 30 \mathrm{~cm}$ & $4.4 \mathrm{a}$ & $5.4 \mathrm{a}$ & $5.6 \mathrm{~b}$ \\
$100 \mathrm{~cm} \times 15 \mathrm{~cm}$ & $3.4 \mathrm{~b}$ & $4.3 \mathrm{~b}$ & $5.0 \mathrm{~b}$ \\
\hline
\end{tabular}

Keterangan: angka yang diikuti oleh huruf yang sama pada kolom yang sama tidak berbeda nyata pada uji lanjut DMRT pada taraf $\alpha=5 \%$

Perlakuan pemangkasan berpengaruh nyata terhadap panjang cabang primer selama pengamatan umur 3 MST sampai 8 MST (Tabel 1). Pengaruh pemangkasan terhadap panjang cabang primer (Tabel 4) menunjukkan bahwa perlakuan tanpa pemangkasan berbeda nyata dengan perlakuan pemangkasan. Panjang rata-rata cabang primer tertinggi pada perlakuan pemangkasan mencapai $34,3 \mathrm{~cm}$, sedangkan pada perlakuan tanpa pemangkasan menunjukkan hasil terendah yaitu $17,6 \mathrm{~cm}$. Menurut Irawati dan Setiari (2006), tanaman dengan jumlah dan panjang cabang yang lebih tinggi memiliki jumlah daun yang lebih banyak sehingga akan menghasilkan asimilat yang lebih banyak.

Tabel 4. Pengaruh pemangkasan pucuk terhadap panjang cabang primer

\begin{tabular}{lcccccc}
\hline \multirow{2}{*}{ Pemangkasan } & \multicolumn{6}{c}{ Umur } \\
\cline { 2 - 7 } & $3 \mathrm{MST}$ & $4 \mathrm{MST}$ & $5 \mathrm{MST}$ & $6 \mathrm{MST}$ & $7 \mathrm{MST}$ & $8 \mathrm{MST}$ \\
\hline & \multicolumn{6}{c}{$\mathrm{cm} /$ tanaman } \\
\hline Pangkas & $9.0 \mathrm{a}$ & $20.1 \mathrm{a}$ & $19.7 \mathrm{a}$ & $25.0 \mathrm{a}$ & $29.7 \mathrm{a}$ & $34.3 \mathrm{a}$ \\
Tanpa Pangkas & $6.7 \mathrm{~b}$ & $12.6 \mathrm{~b}$ & $11.1 \mathrm{~b}$ & $13.8 \mathrm{~b}$ & $15.0 \mathrm{~b}$ & $17.6 \mathrm{~b}$ \\
\hline
\end{tabular}

Keterangan: angka yang diikuti oleh huruf yang sama pada kolom yang sama tidak berbeda nyata pada uji lanjut DMRT pada taraf $\alpha=5 \%$ 
Perlakuan jarak tanam berpengaruh nyata terhadap panjang cabang primer primer pada umur 7 MST sampai 8 MST (Tabel 1). Pengaruh jarak tanam terhadap panjang cabang primer (Tabel 5) menunjukkan bahwa perlakuan jarak tanam $100 \mathrm{~cm} \times 30 \mathrm{~cm}$ tidak berbeda nyata dengan perlakuan jarak tanam $100 \mathrm{~cm} \times 25 \mathrm{~cm}$ tetapi berbeda nyata dengan perlakuan jarak 100 $\mathrm{cm}$ x $30 \mathrm{~cm}$. Pengamatan pada umur 8 MST menunjukkan bahwa jarak tanam $100 \mathrm{~cm}$ x $30 \mathrm{~cm}$ menghasilkan panjang cabang primer tertinggi dengan rata-rata $32,0 \mathrm{~cm}$ dan terendah pada jarak tanam $100 \mathrm{~cm}$ x $15 \mathrm{~cm}$ dengan rata-rata $19,9 \mathrm{~cm}$.

Tabel 5. Pengaruh jarak tanam terhadap panjang cabang primer

\begin{tabular}{lrrr}
\hline \multirow{2}{*}{ Jarak Tanam } & \multicolumn{3}{c}{ Umur } \\
\cline { 2 - 4 } & & 7 MST & cm/tanaman \\
\cline { 2 - 4 } $100 \mathrm{~cm} \times 30 \mathrm{~cm}$ & $26.0 \mathrm{a}$ & $32.0 \mathrm{a}$ \\
$100 \mathrm{~cm} \times 25 \mathrm{~cm}$ & $23.6 \mathrm{a}$ & $26.2 \mathrm{a}$ & \\
$100 \mathrm{~cm} \times 15 \mathrm{~cm}$ & $17.2 \mathrm{~b}$ & $19.9 \mathrm{~b}$ & \\
\hline
\end{tabular}

Keterangan: angka yang diikuti oleh huruf yang sama pada kolom yang sama tidak berbeda nyata pada uji lanjut DMRT pada taraf $\alpha=5 \%$

Jumlah dan Panjang Cabang Sekunder. Cabang sekunder merupakan cabang yang tumbuh pada ketiak daun cabang primer. Cabang sekunder biasanya mulai tumbuh pada saat cabang primer sudah memiliki pucuk yang sempurna. Pertumbuhan dan waktu awal pengamatan cabang sekunder tidak berbeda dengan cabang primer.

Tabel 6. Pengaruh pemangkasan pucuk terhadap jumlah cabang sekunder

\begin{tabular}{|c|c|c|c|}
\hline \multirow{2}{*}{ Pemangkasan } & \multicolumn{3}{|c|}{ Umur } \\
\hline & $6 \mathrm{MST}$ & $7 \mathrm{MST}$ & $8 \mathrm{MST}$ \\
\hline & & oang/tan & \\
\hline Pangkas & $4.7 \mathrm{a}$ & $16.3 \mathrm{a}$ & $17.3 \mathrm{a}$ \\
\hline Tanpa Pangkas & $1.0 \mathrm{~b}$ & $6.2 \mathrm{~b}$ & $7.4 \mathrm{~b}$ \\
\hline
\end{tabular}

Perlakuan pemangkasan berpengaruh nyata terhadap jumlah cabang sekunder primer pada umur 6 MST sampai 8 MST (Tabel 1). Pengaruh pemangkasan terhadap jumlah cabang sekunder (Tabel 6) menunjukkan bahwa perlakuan tanpa pemangkasan berbeda nyata dengan perlakuan pemangkasan. Pengamatan pada umur 8 MST menunjukkan bahwa jumlah cabang sekunder tertinggi pada perlakuan pemangkasan dengan rata-rata 17 cabang dan terendah pada perlakuan tanpa pemangkasan dengan rata-rata 7 cabang.

Tabel 7. Pengaruh pemangkasan pucuk terhadap panjang cabang sekunder

\begin{tabular}{llll}
\hline \multirow{2}{*}{ Pemangkasan } & \multicolumn{3}{c}{ Umur } \\
\cline { 2 - 4 } & $6 \mathrm{MST}$ & $7 \mathrm{MST}$ & $8 \mathrm{MST}$ \\
\hline \multirow{3}{*}{ Pangkas } & $3.9 \mathrm{a}$ & $3.7 \mathrm{a}$ & $5.6 \mathrm{a}$ \\
Tanpa Pangkas & $1.1 \mathrm{~b}$ & $2.8 \mathrm{~b}$ & $4.7 \mathrm{~b}$ \\
\hline
\end{tabular}

Keterangan: angka yang diikuti oleh huruf yang sama pada kolom yang sama tidak berbeda nyata pada uji lanjut DMRT pada taraf $\alpha=5 \%$

Perlakuan pemangkasan berpengaruh nyata terhadap panjang cabang sekunder pada umur 6 MST sampai 8 MST (Tabel 1). Pengaruh pemangkasan terhadap panjang cabang sekunder (Tabel 7) menunjukkan bahwa perlakuan tanpa pemangkasan berbeda nyata dengan perlakuan pemangkasan. Pengamatan pada umur 8 MST menunjukkan bahwa perlakuan pemangkasan menghasilkan panjang cabang sekunder tertinggi dengan rata-rata $5,6 \mathrm{~cm}$ dan terendah pada perlakuan tanpa pemangkasan dengan rata-rata 4,7 $\mathrm{cm}$.

\section{Hasil panen bibit}

Jumlah stek. Stek batang dan stek pucuk dipanen pada umur 9 MST (> 2 bulan). Stek dikelompokan ke dalam 3 ukuran, yaitu ukuran $25 \mathrm{~cm}, 20 \mathrm{~cm}$, dan $15 \mathrm{~cm}$ (Gambar Lampiran 2). Menurut Djufry 
et al. (2011), panjang sulur yang lebih pendek pada umumnya dimiliki oleh varietas dengan ruas buku yang rapat. Penjelasan sebelumnya menerangkan bahwa panjang rata-rata batang utama ubi cilembu pada penelitian ini yaitu 101,2 $\mathrm{cm}$, cukup pendek jika dibandingkan dengan varietas ubi lainnya sehingga dapat disimpulkan bahwa ubi cilembu memiliki ruas yang rapat. Pengamatan dilapang menunjukkan bahwa ukuran stek $25 \mathrm{~cm}$ memiliki 5 buku (6 ruas), ukuran 20 $\mathrm{cm}$ memiliki 4 buku (5 ruas), dan ukuran $15 \mathrm{~cm}$ memiliki 3 buku (4 ruas). Menurut Irawati dan Setiari (2006), tunas lateral akan tumbuh lebih banyak pada tanaman yang memiliki jumlah ruas lebih banyak.

Penelitian pada umumnya menggunakan stek berukuran $25 \mathrm{~cm}$, salah satunya penelitian yang dilakukan oleh Rahmania dan Kurniawati (2014) menjelaskan bahwa stek 5 buku memiliki jumlah tunas terbanyak karena pada buku terdapat mata tunas sehingga semakin banyak jumlah buku maka semakin banyak mata tunas yang akan tumbuh menjadi tunas baru. Stek 5 buku juga memberikan hasil panen tertinggi dibandingkan dengan stek kurang dari 5 buku. Santoso et al. (2008) menjelaskan bahwa ukuran stek $30 \mathrm{~cm}, 25$ $\mathrm{cm}$, dan $20 \mathrm{~cm}$ memberikan pengaruh yang tidak berbeda nyata terhadap pertumbuhan tanaman jarak pagar. Penggunaan stek panjang memerlukan bahan tanam yang lebih banyak dibandingkan stek pendek sehingga penggunaan stek pendek akan lebih efisien, namun ukuran stek harus menjadi pertimbangan dalam perbanyakan vegetatif karena terkait dengan keberadaan cadangan makanan yang umumnya berupa karbohidrat. Cadangan makanan yang dimiliki masing-masing stek akan mempengaruhi pertumbuhan dan perkembangan bibit. Handriatni dan Susilo (2010) menerangkan bahwa karbohidrat merupakan hasil dari proses fotosintesis yang terjadi pada daun dan adanya metabolism yang meningkat. Proses metabolisme yang meningkat akan mempercepat pertumbuhan vegetatif sehingga mendorong terbentuknya kandungan karbohidrat di dalam tanaman.

Tabel 8. Pengaruh pemangkasan pucuk terhadap jumlah stek batang dan stek pucuk

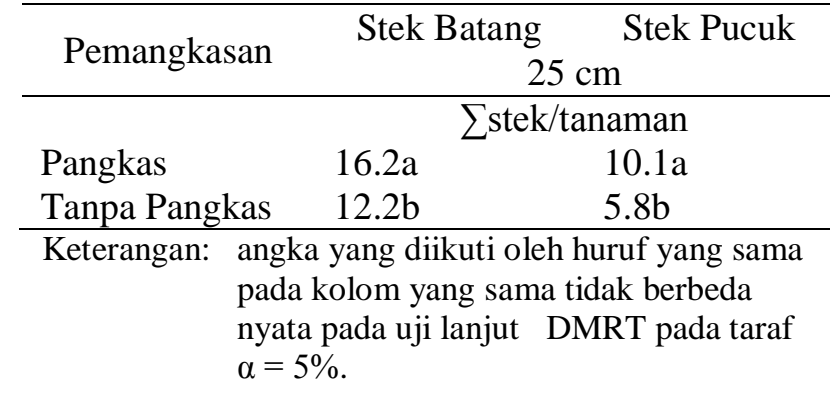

Perlakuan pemangkasan berpengaruh nyata terhadap jumlah stek batang berukuran $25 \mathrm{~cm}$ (Tabel 1). Pengaruh pemangkasan terhadap jumlah stek batang (Tabel 8) menunjukkan bahwa perlakuan tanpa pemangkasan berbeda nyata dengan perlakuan pemangkasan. Jumlah stek batang berukuran $25 \mathrm{~cm}$ tertinggi pada perlakuan pemangkasan dengan rata-rata 16 stek dan terendah pada perlakuan tanpa pemangkasan dengan rata-rata 12 stek.

Perlakuan pemangkasan berpengaruh nyata terhadap jumlah stek pucuk berukuran $25 \mathrm{~cm}$ (Tabel 1). Pengaruh pemangkasan terhadap jumlah stek pucuk (Tabel 8) menunjukkan bahwa perlakuan tanpa pemangkasan berbeda nyata dengan perlakuan pemangkasan. Perlakuan pemangkasan menghasilkan jumlah stek pucuk berukuran $25 \mathrm{~cm}$ lebih banyak dengan rata-rata 10 stek dibandingkan perlakuan tanpa pemangkasan dengan rata-rata 6 stek.

Pertumbuhan panjang batang terjadi lebih cepat pada perlakuan tanpa pemangkasan tapi perlakuan ini menghasilkan jumlah stek batang dan stek pucuk yang lebih rendah dibandingkan perlakuan pemangkasan, hal ini diduga karena stek batang dan stek pucuk pada perlakuan pemangkasan dihasilkan bukan dari pertumbuhan panjang batang tapi dari pertumbuhan samping (tunas-tunas lateral).

Perlakuan jarak tanam berpengaruh nyata terhadap jumlah stek pucuk berukuran $25 \mathrm{~cm}$ (Tabel 1). Perlakuan jarak tanam $100 \mathrm{~cm}$ x $30 \mathrm{~cm}$ menghasilkan jumlah stek pucuk berukuran $25 \mathrm{~cm}$ lebih banyak dengan rata-rata 10 stek dibandingkan jarak tanam $100 \mathrm{~cm}$ x $20 \mathrm{~cm}$ dan $100 \mathrm{~cm} \mathrm{x} 15 \mathrm{~cm}$ dengan rata-rata 7 stek dan 6 stek.

Penelitian yang dilakukan oleh Djufry et al. (2011) menjelaskan bahwa stek batang maupun stek pucuk menghasilkan pertumbuhan dan produksi ubi jalar yang tidak berbeda nyata. Menurut Febrianto dan Chozin (2014), stek pucuk memiliki pertumbuhan yang lebih cepat, meskipun hasilnya tidak berbeda nyata dengan stek batang karena pertumbuhan stek pucuk dipengaruhi oleh auksin.

\section{Multiplication Rate}

Multiplication Rate pada penelitian ini dapat diketahui pada perlakuan pemangkasan dan jarak tanam, meskipun perlakuan jarak tanam hanya berpengaruh nyata terhadap jumlah stek pucuk. Multiplication Rate pada perlakuan tanpa pemangkasan adalah 1 bahan tanam menghasilkan 17 stek per tanaman sedangkan pada perlakuan pemangkasan ialah 1 bahan tanam menghasilkan 26 stek/tanaman. Multiplication Rate pada 
perlakuan jarak tanam $100 \mathrm{~cm}$ x $30 \mathrm{~cm}$ adalah 1 bahan tanam menghasilkan 27 stek/tanaman, pada jarak tanam $100 \mathrm{~cm} \times 25 \mathrm{~cm}$ adalah 1 bahan tanam menghasilkan 20 stek/tanaman, dan pada jarak tanam $100 \mathrm{~cm} \times 15 \mathrm{~cm}$ adalah 1 bahan tanam menghasilkan 18 stek/tanaman. Hasil tersebut menunjukkan bahwa perlakuan pemangkasan dan perlakuan jarak tanam $100 \mathrm{~cm} \mathrm{x}$ $30 \mathrm{~cm}$ lebih efektif dalam mempercepat produksi bibit dibandingkan perlakuan tanpa pemangkasan.

\section{Hasil Panen Umbi}

Jumlah Umbi. Perlakuan pemangkasan dan jarak tanam tidak berpengaruh nyata terhadap jumlah umbi (Tabel 1). Umbi yang dipanen dikelompokan ke dalam 3 ukuran, yaitu bobot < 150 g, 150 g sampai 200 g, 200 g sampai 300 g (Gambar Lampiran 3). Penelitian ini menunjukkan bahwa hasil panen umbi didominasi oleh umbi dengan bobot kurang dari $150 \mathrm{~g}$ dengan persentase $95,9 \%$ dari total rata-rata 6 umbi/petak (Tabel Lampiran 4). Bobot tersebut sangat jauh di bawah bobot umbi ideal yaitu $200 \mathrm{~g}$ sampai $300 \mathrm{~g}$. Total Bobot umbi panen untuk luasan lahan 180 $\mathrm{m}^{2}$ adalah 0,03 ton atau setara dengan 1,5 ton/ha. Hasil ini juga sangat jauh di bawah rata-rata produksi nasional ubi cilembu yang mencapai 20 ton/ha.

Faktor-faktor yang menyebabkan umbi berukuran kecil diantaranya, (1) panen bibit yang dilakukan umur 2 bulan mempengaruhi perkembangan umbi karena tanaman berusaha untuk memperbaiki pertumbuhan vegetatifnya sehingga pertumbuhan umbi menjadi terhambat, (2) dosis pupuk $\mathrm{KCl}$ yang digunakan rendah, dalam penelitian ini pupuk urea yang paling banyak digunakan sehingga pertumbuhan vegetatif berlangsung lebih lama, (3) kondisi tanah, umbi dapat tumbuh subur ditanah berpasir untuk mempermudah perakaran dan pembentukan umbi, sedangkan lahan yang digunakan dalam penelitian ini memiliki tekstur tanah liat yang lengket dan sangat gembur, (4) curah hujan tinggi, saat penelitian curah hujan mencapai 287,5 mm. Menurut klasifikasi iklim Schmidth dan Ferguson, bulan dengan curah hujan > $100 \mathrm{~mm}$ termasuk dalam bulan basah. Menurut Hariati et al. (2012) menjelaskan bahwa curah hujan tinggi menyebabkan pupuk kalium yang memiliki sifat mudah tercuci menjadi tidak tersedia bagi tanaman, (5) waktu panen, panen umbi pada penelitian ini dilakukan pada umur 18 MST $(4,5$ bulan) sedangkan menurut Balitbangtan (2001), umur panen umbi varietas cilembu adalah 5 bulan sampai 7 bulan.
Unsur nitrogen yang terkandung dalam pupuk urea sangat dibutuhkan oleh tanaman untuk perkembangan vegetatif terutama untuk perkembangan daun, meningkatkan warna hijau daun, dan pembentukan cabang, sedangkan unsur kalium pada $\mathrm{KCl}$ dapat mempercepat proses fotosintesis. Hasil fotosintesis dapat merangsang pembentukan umbi lebih besar (Sumarni et al., 2012).

\section{Analisis Korelasi}

Hasil uji korelasi (Tabel 9) menunjukkan bahwa pertumbuhan vegetatif seperti pada panjang cabang primer, jumlah dan panjang cabang sekunder berkolerasi negatif dengan panjang batang. Semakin tinggi panjang batang maka pertumbuhan cabang primer dan cabang sekunder semakin lambat, hal ini diduga karena pertumbuhan panjang batang ubi jalar dipengaruhi oleh dominasi apikal yang dapat menghambat pertumbuhan tunas-tunas samping.

Pertumbuhan vegetatif berupa panjang cabang sekunder berkorelasi positif dengan jumlah cabang sekunder. Semakin tinggi jumlah cabang sekunder maka pertumbuhan panjang cabang sekunder akan semakin meningkat. Hasil ini dilapang tidak selalu benar, hal ini diduga karena pertumbuhan panjang cabang sekunder pada penelitian ini dihitung berdasarkan hasil rata-rata dari total jumlah cabang sekunder yang memiliki ukuran panjang dan pendek.

Hasil panen bibit berupa stek pucuk berkolerasi negatif dengan panjang batang. Semakin tinggi pertumbuhan panjang batang maka hasil panen stek pucuk semakin sedikit, hal ini diduga karena pertambahan panjang batang menghambat pertumbuhan tunas-tunas samping. Tunas-tunas tersebut akan berkembang menjadi cabang lateral yang memiliki pucuk sehingga batang yang memiliki ukuran lebih panjang akan menghasilkan stek pucuk yang lebih sedikit

Hasil panen bibit berupa stek pucuk berkorelasi positif dengan jumlah stek batang. Semakin banyak panen stek batang maka panen stek pucuk juga akan semakin banyak, hal ini karena batang memiliki buku tempat tumbuhnya tunas-tunas samping sehingga stek batang dimungkinkan memiliki cabang lateral yang dapat dijadikan stek pucuk.

Hasil panen bibit berupa stek batang dan stek pucuk berkorelasi positif dengan panjang cabang primer. Semakin tinggi pertumbuhan cabang primer maka jumlah stek batang dan stek pucuk akan semakin meningkat. Menurut Sutapradja (2008), jumlah cabang berkolerasi positif dengan jumlah benih total pertanaman yang akan dipanen. 
Tabel 9. Hasil uji korelasi antar peubah pengamatan

\begin{tabular}{|c|c|c|c|c|c|}
\hline & & JP & $\mathrm{PP}$ & JS & PS \\
\hline JP & $0,188^{\text {tn }}$ & & & & \\
\hline $\mathrm{PP}$ & $-0,825^{*}$ & $0,154^{\mathrm{tn}}$ & & & \\
\hline JS & $-0,984^{* *}$ & $-0,098^{\text {tn }}$ & $0,782^{\text {tn }}$ & & \\
\hline PS & $-0,936^{* *}$ & $-0,179^{\mathrm{tn}}$ & $0,664^{\mathrm{tn}}$ & $0,950^{* *}$ & \\
\hline SB & $-0,678^{\operatorname{tn}}$ & $0,520^{\mathrm{tn}}$ & $0,869^{*}$ & $0,685^{\mathrm{tn}}$ & $0,535^{\mathrm{tn}}$ \\
\hline SP & $-0,818^{*}$ & $0,143^{\text {tn }}$ & $0,981^{* *}$ & $0,775^{\text {tn }}$ & $0,611^{\text {tn }}$ \\
\hline UK & $0,590^{\operatorname{tn}}$ & $0,034^{\mathrm{tn}}$ & $-0,652^{\text {tn }}$ & $-0,554^{\mathrm{tn}}$ & $-0,680^{\text {tn }}$ \\
\hline US & $0,467^{\text {tn }}$ & $-0,556^{\mathrm{tn}}$ & $-0,498^{\text {tn }}$ & $-0,518^{\mathrm{tn}}$ & $-0,608^{\text {tn }}$ \\
\hline
\end{tabular}

Keterangan : PB: Panjang Batang; JP : Jumlah Cabang Primer; PP : Panjang Cabang Primer; JS : Jumlah Cabang Sekunder; PS : Panjang Cabang Sekunder; SB : Jumlah Stek Batang; SP : Jumlah Stek Pucuk; UK : Jumlah Umbi Kecil; US : Jumlah Umbi Sedang.

\section{KESIMPULAN}

Perlakuan pemangkasan menghasilkan pertumbuhan vegetatif lebih baik dibandingkan perlakuan tanpa pemangkasan. Perlakuan pemangkasan juga menghasilkan rata-rata jumlah stek batang maupun stek pucuk lebih banyak dibandingkan perlakuan tanpa pemangkasan. Jarak tanam $100 \mathrm{~cm}$ x $30 \mathrm{~cm}$ menghasilkan ratarata jumlah stek pucuk lebih banyak dari perlakuan jarak tanam $100 \mathrm{~cm}$ x $25 \mathrm{~cm}$ dan 100 $\mathrm{cm} \times 15 \mathrm{~cm}$. Umbi yang dihasilkan oleh kombinasi perlakuan pemangkasan dan jarak tanam menghasilkan total bobot panen sebesar 1,5 ton/ha. Hasil ini menunjukkan bahwa kedua perlakuan tersebut tidak dapat digunakan dalam memproduksi bibit dan umbi secara bersamaan.

\section{DAFTAR PUSTAKA}

Abadi, I.J., Sebayang H.T., Widaryanto E. 2013. Pengaruh jarak tanam dan teknik pengendalian gulma pada pertumbuhan dan hasil tanaman ubi jalar (Ipomoea batatas L.). Jurnal Produksi Tanaman 1(2):8-16.

Arifin, Z., Samekto R., Nurhayati, D.R. 2015. Pengaruh macam pupuk organik dan panjang stek terhadap pertumbuhan tanaman buah naga. Jurnal Inovasi Pertanian 14(1):99-110.

[Balitbangtan] Balai Penelitian dan Pengembangan Pertanian. 2001. Deskripsi ubi jalar varietas cilembu. http://pangan.litbang.pertanian.go.id/varieta s-137.html [12 Mei 2016].

$\begin{array}{ccr}\text { [Balitbangtan] Balai } & \text { Penelitian } & \text { dan } \\ \text { Pengembangan } & \text { Pertanian. } & 2016 . \\ \text { Diversifikasi produk ubi jalar sebagai bahan } & \text { bahas } \\ \text { pangan } & \text { substitusi } & \text { beras. } \\ \text { http://pangan.litbang.pertanian.go.id/berita- } & \\ \text { 314-diversifikasi-produk-ubi-jalar-sebagai- }\end{array}$

bahan-pangan-substitusi-beras.html [12 mei 2016].

[BPS] Badan Pusat Statistik. 2015. Luas panen ubi jalar. www.bps.go.id/linkTableDinamis/view/id/8 82. [15 Oktober 2015].

[BPS] Badan Pusat Statistik. 2015. Produksi ubi jalar. www.bps.go.id/linkTableDinamis/view/id/8 82. [15 Oktober 2015].

Djufry, F., Lestari M.S., SoflanitA.A. 2011. Pertumbuhan dan produksi ubi jalar di dataran rendah pada berbagai varietas dan sumber stek. J. Agrivigor 10(3):228-234.

Febrianto, Y., Chozin M.A. 2014. Pengaruh jarak tanam dan jenis stek terhadap kecepatan penutupan Arachis pintoi Krap. dan Greg. sebagai biomulsa pada pertanaman tomat (Licopersicon esculentum M.). Bul. Agrohorti 2(1):37-41.

Handriatni, A., Susilo. 2010. Upaya peningkatan kangkung darat (Ipomea reptans Poir) dengan pemangkasan dan pemberian pupuk $\mathrm{N}$ di lahan pantai. PENA Akuatika 1(1):111 .

Hariati, I., Nisa T.C., Barus A. 2012. Tanggap pertumbuhan dan produksi bengkuang terhadap beberapa dosis pupuk kalium dan jarak tanam. Jurnal Agroekoteknologi 1(1):99-108.

Hasyim, A., Yusuf M. 2008. Diversifikasi produk ubi jalar sebagai bahan pangan substitusi beras. Pusat Penelitian dan Pengembangan Tanaman Pangan. Tabloit Sinar Tani.

Irawati, H., Setiari N. 2006. Pertumbuhan tunas lateral tanaman nilam setelah dilakukan pemangkasan pucuk pada ruas yang 
berbeda. Laboratorium Biologi Struktur dan Fungsi Tumbuhan. Fakultas Matematika dan Ilmu Pengetahuan Alam, Universitas Diponogoro.

[Kemenristek] Kementrian Riset dan Teknologi. 2000. Ubi jalar. www.ristek.go.id. [15 Oktober 2015]. Munawaroh N. dan Aziz S.A. 2013. Pertumbuhan dan produksi daun torbangun (Plectranthus amboinicus Spreng.) dengan pemupukan organik dan pemangkasan. Bul. Agrohorti 1(4):122-132.

Panggabean, F.DM., Mawami L., Nissa T.C. 2014. Respon pertumbuhan dan produksi bengkuang terhadap waktu pemangkasan dan jarak tanam. Jurnal Agroekologi 2[2]:702-711.

Purnama, R.H., Santosa S.J., Hardiatmi S. 2013. Pengaruh dosis pupuk eceng gondok dan jarak tanam terhadap pertumbuhan dan hasil tanaman sawi. INNOFARM 12(2):95107.

Rahmania R. dan Kurniawati A. Penentuan ukuran stek kumis kucing dan dosis pupuk kandang pada cara tanam langsung. J. Hort. Indonesia 5(3):189-202.

Santoso, B.B., Hasnam, Hariyadi, Susanto S., Purwoko B.S. 2008. Perbanyakan vegetatif tanaman jarak pagar (Jatropha curcas 1.) dengan stek batang: pengaruh panjang dan diameter stek. Bul. Agron. 36(3):255 262.

Sasongko, L.A. 2009. Perkembangan ubi jalar dan peluang pengembangannya untuk mendukung program percepatan diversifikasi konsumsi pangan di Jawa Tengah. Mediagro 5[1]:36-43.

Srirejeki, D.I., Maghfoer M.D., Herlina N. 2015. Aplikasi PGPR dan dekamon serta pemangkasan pucuk untuk meningkatkan produktivitas tanaman buncis (Phaseolus vulgaris 1.) tipe tegak. Jurnal Produksi Tanaman 3[4]:302 - 310 .

Suharsi, T.K., Surahman M., RahmataniS.F. 2013. Pengaruh jarak tanam dan pemangkasan tanaman pada produksi dan mutu benih koro pedang (Canavalia enziformis). JIPI 18 (3): 172-177.

Sumarni, N., Rosliani R., Suwandi. 2012. Optimasi jarak tanam dan dosis pupuk NPK untuk produksi bawang merah dari benih umbi mini di dataran tinggi. J. Hort. 22(2):147-154.

Sutapradja, H. J. 2008. Pengaruh jarak tanam dan ukuran umbi bibit terhadap pertumbuhan dan hasil kentang varietas granola untuk bibit. J. Hort. 18(2):155-159.

Sutapradja, H. J. 2008. Pengaruh pemangkasan pucuk terhadap hasil dan kualitas benih lima kultivar mentimun. J. Hort. 18(1):16-20.

Widowati, R. 2000. Bercocok tanam ubi jalar. Agdex 174:20.

Yudianto, A.A., Fajrin S., Aini N. 2015. Pengaruh jarak tanam dan pembumbunan terhadap pertumbuhan dan hasil tanaman garut. Jurnal Produksi Tanaman 3(2):172181. 